\title{
Development of Learning Devices Based on Realistic Mathematics Education to Improve Students' Spatial Ability and Motivation
}

\author{
Shulha Kynanda Putri ${ }^{1 *}$, Hasratuddin ${ }^{1}$, Edi Syahputra ${ }^{1}$ \\ ${ }^{1}$ State University of Medan, INDONESIA \\ *CORRESPONDENCE: $\square$ akindy66@gmail.com
}

\begin{abstract}
The aims of this research was to find the effectiveness of learning devices based on realistic mathematics education, as well as improving mathematic spatial ability and motivation of SMP Negeri 2 Pulo Bandring students' grade IX. This research is a development research using the Dick $\&$ Carey development model. The results of the analysis of the data obtained indicate that learning materials based on realistic mathematics education met the criteria of effectiveness, it was found that students completed classically $\geq 85 \%$ of students got a minimum score of $\geq 75$, achievement of learning objectives, positive students responses and learning time equal to ordinary learning. Based on the results of the study, it was suggested that mathematics teachers make an effort mathematica learning using learning devices based on realistic mathematics education.
\end{abstract}

Keywords: Dick \& Carey model, development research, learning materials, realistic mathematics education, spatial ability, motivation

\section{INTRODUCTION}

One of knowledge that has an important role to improve quality resources is mathematics education. The new paradigm in mathematics education emphasizes more at students who must be active in training and developing their abilities (Hadi, 2017). Many ongoing efforts by the government in improving the quality of teaching and learning mathematics, such as the provision of supporting learning devices such as syllabus, learning implementation plans, students' book until the provision of teaching aids and professional training for mathematics teacher (Ansari, 2016). The learning devices should fulfill the effectiveness of mathematics learning (Azwar \& Surya, 2017).

In addition, students are faced with mathematical problems that originate from the student environment. The approach of Realistic Mathematics Education (PMR) comes from contextual problems, where in this situation students must be active in learning and teacher acts as a facilitator (Safitri, Surya, Syahputra \& Simbolon, 2017). In line with the opinion of Sapta, Hamid and Syahputra (2018) "In the learning that the teacher wants is dominant longer, but more emphasis on two-way interaction between teachers and students".

Hadi (2017) also acknowledged that "Concept of PMR is in line with the need to improve mathematics education in Indonesia which is dominated by the problem of how to increase students' understanding of mathematics and develop reasoning power". This is an advantage so every math teacher in Indonesia must know that PMR is very feasible to use in the learning process.

This was obtained when the researchers conducted preliminary observations in class IX SMP Negeri 2 Pulo Bandring by giving a test question on mathematic spatial abilities and motivation of students whose

Article History: Received 27 January $2019 \bullet$ Revised 5 February $2019 \bullet$ Accepted 7 February 2019

(C) 2019 by the authors; licensee Modestum Ltd., UK. Open Access terms of the Creative Commons Attribution 4.0 International License (http://creativecommons.org/licenses/by/4.0/) apply. The license permits unrestricted use, distribution, and reproduction in any medium, on the condition that users give exact credit to the original author(s) and the source, provide a link to the Creative Commons license, and indicate if they made any changes. 
analysis was based on both aspects Aspect of mathematic spatial ability according to Maier (1998), are: (1) spatial perception, (2) visualization, (3) mental rotation, (4) spatial relations and (5) spatial orientation. While, aspects of motivation are intrinsic and extrinsic come from of students (Tohidi \& Jabbari, 2012).

Furthermore, indicators from the five aspects on mathematic spatial abilities are: (1) can observe objects or parts of objects that are placed in a fixed form in a horizontal or vertical position, (2) can state the true condition of a change in the composition or part of a particular object, (3) can express the shape of a 2 dimensional or 3 dimensional object as a result of rotation, (4) can express the spatial form of an object and its relation between one part and another part, and (5) can express the shape of an object when viewed from various perspectives and certain situations. From fifth indicators, researcher arranged diagnostic tests to students of class IX SMP Negeri 2 Pulo Bandring.

However, students were reported to have difficulties in mathematics spatial abilities (Sugiarni, Alghifari $\&$ Ifanda, 2018). The result of interview with the teachers' SMP Negeri 2 Pulo Bandring that mathematics learning was very difficult for students. It was also found that mathematics as a school subject raises a lot of negative emotions among students and their parents. It is seen as difficult, detached from reality, full of useless in everyday life definitions and theorems (Pieronkiewicz, 2014). The same matter, the low mathematical spatial ability of students, also reported that when making observations at SMP Negeri 2 Pulo Bandring. With a test in the form of a description to describe students' ability to solve mathematic problems, obtain similar information that spatial ability is very low.

Based on the student answer sheet on the mathematics spatial ability test, the researcher find that the student difficulty in visualizing an object. So that, researcher was interviewing some of student and a lowability student said that he did not understand how to change an object position. He claimed to confuse of looking for an object. Then, the students did not complete writing what they knew. For high-ability students, they're says that understands well and asked in the question. In this case, the researcher was doing an analysis of student answer errors.

From the above problems it was found that the teacher must make learning materials to improve mathematical spatial ability and motivation of students grade IX SMP Negeri 2 Pulo Bandring. In conclusion, the researcher was choosing realistic mathematics education approach to improve both of them. Learning tools developed are not only useful for improving students ability but are useful for teachers to improve their teaching quality and professional development (Azwar, Surya \& Saragih 2017). In this case the researcher was choosing development research (Sukmadinata, 2012). Development that can be done is the development of learning materials.

Learning materials is very important in learning mathematics. Learning materials was developed could be improved students' mathematical spatial ability and motivation. Not only that, response the students were positive in learning mathematics. Time in learning was same with ordinary learning. The importance of developing learning devices is based on several reasons, among others, the availability of materials according to the demands of the curriculum, target characteristics, and demands for problem solving learning (Fitriani, 2014).

\section{Mathematical Spatial Ability}

Spatial ability of mathematics is the ability associated with students' intelligence in learning mathematics. Intelligence is defined as a general mental ability to learn and apply knowledge in manipulating the environment and the ability to think abstractly. Gardner (1989) found seven types of intelligence possessed by humans, namely logical-mathematical, linguistic, musical, spatial, bodily-kinesthetic, interpersonal, intrapersonal. Seventh of intelligences are possessed by humans, not even human beings who can maximize the overall intelligence. Relationship of intelligence with students namely multiple intelligences already exists in students. This means that multiply intelligence is already in the education system in student schools today.

Alkalbani and Alwahaibi (2015) assert that "As learners are the most important elements of any educational system, dealing with them should not be random. Their needs, learning styles, strengths and weaknesses should be effective and meaningful learning. MI is a new model of learning that helps students to learn effectively “. Quintero, Salinas, Mendivil and Ramirez (2015) stated that: "Spatial ability is the basic perception skill for recognizing and understanding objects in the physical world. In the study of numerous sciences, such as mathematics, physics and engineering, this ability is crucial.

Hasratuddin (2014) explain that mathematics has a great potential to provide various abilities, and attitudes needed by humans so that they can live intelligently (Intelligent) in their environment. He added if 
one of the abilities that can be obtained is the ability to observe and imagine geometric buildings that exist in nature along with the spatial properties of each of these objects. The spatial ability of mathematics in students in Indonesia is very low (Zulfahmi, Syahputra \& Fauzi (2017). Sari, Syahputra and Surya (2018) conducted an analysis of the spatial abilities of students. Their research that spatial ability of students made some of students who have high, middle and low spatial abilities of mathematics. It was also found by researchers at SMP Negeri 2 Pulo Bandring students, based on the spatial abilities test given to grade IX students' of SMP 2 Pulo Bandring are low.

\section{Motivation}

In mathematics learning, not only cognitive abilities needed attention. Affective abilities where is a student's mental processes are also something important. Colomeischi and Colomeischi (2014) revealed that "Learning mathematics was a challenge for most of the student. Either lack of motivation or hopelessness makes many students to say "I'm not good in math" before they even try to solve mathematical problems. Therefore we need strong motivation in learning mathematics.

According to Tohidi and Jabbari (2012) the concept of motivation is divided into two namely Intrinsic and extrinsic of motivation. Both interact with each other in achieving learning achievement. Intrinsic motivation is a motivation that comes from the needs and goals of the students themselves. Intrinsic motivation is in the form of successful desires and desires, encouragement of learning needs and hopes for dreams. While, extrinsic motivation is a factor come from outside of students, namely in the form of appreciation, a conducive learning environment and interesting learning activities. According to Iskandar, the indicators that show students have the motivation to learn are as follows: (1) the desire or desire to succeed in learning; (2) there is desire, enthusiasm and need for learning; (3) having hopes and aspirations for the future; (4) learning to fulfill obligations; (5) there is an award in the learning process (Farida, Herkulana \& Salim, 2015).

Many study in terms to improving students' motivation. Sabrida (2016) states that by developing effective teaching materials through realistic mathematics education able to improve student learning motivation. Suranto (2015) found that learning motivation can affect learning achievement, meaning that there is a significant influence between learning motivation and learning achievement. Tohidi and Jabbari (2012) asked that "Motivation is of particular interest to educational psychologists because of the crucial role it plays in student learning". So that from the opinions mentioned above it turns out that motivation is needed in learning.

\section{Realistic Mathematics Education}

Vigotsky (1978) mentions the use of real world contexts will be more meaningful for students, because they are directly confronted with the situation they face in their environment. Indirectly the students' interest in learning will be more maximal and want to continue learning mathematics in other problems they might face in the outside world. Students learn to manipulate objects directly with the real world and environment, so that at this stage face to face with real world concepts. Regarding learning, Vygotsky put forward the four principles stated by Slavin (Trianto, 2011) as follows: (1) Sociocultural. The learning approach that is deemed appropriate is cooperative learning. Vygotsky states that students learn through interaction with adults or more capable friends; (2) ZPD (zone of proximal development). That student will be able to learn concepts as well if they are in ZPD. Students work in ZPD if students cannot solve the problem themselves, but can solve the problem after getting help from an adult or friend (peer); (3) Vygostky emphasizes scaffolding. Students are given problems that are complex, difficult, and realistic, and then given enough assistance in solving them. (4) development of depart from the social field to the individual field. Bruner (1961) states that children develop in three stages of development, namely as follows: (1) Enactive, at this stage children learn to manipulate objects directly. (2) Iconics, at this stage the children's activities begin to involve mentality which is a picture of objects. (3) Symbolic, at the stage of manipulating symbols and having nothing to do with objects directly.

According to Piaget (Trianto, 2011) logical-mathematical knowledge is knowledge that is formed by thinking about the experience of an object or a particular event, this knowledge is obtained from abstractions based on coordination, relations or use of objects. Logical-mathematical knowledge can develop only if the child acts on that object. The child forms logical mathematical knowledge because knowledge is not in the object itself like physical knowledge. Knowledge must be formed from the child's thinking about the object. Here, objects are only a medium to let construction happen. Realistic Mathematics Education approach was initiated by a group of mathematical educators in Indonesia. The initial motivation was to find a substitute 
for modern mathematics which had been abandoned in the early 1990s. The old search finally found the answer through RME (Realistic Mathematics Education) which was successfully implemented in the Netherlands since the 1970s and also in several other countries.

Syahputra (2013) argues in general that the Realistic Mathematics Education approach consists of five characteristics, namely: (1) the use of "real context" (2) the use of "models" (3) the connection between and between mathematical topics; (4) the use of interactive methods and (5) appreciate variations in answers and student contributions. Sembiring (2010) asserts that "Realistic Mathematical Approach is a movement to reform mathematics education in Indonesia. So it is not only a method of learning mathematics, but also an effort to transform ". In real world PMR (real world) can be used as a starting point for the development of mathematical ideas and concepts. Sadiq (2010) states that "Real world as a concrete real world is transferred to student through mathematical application". De Lange (Hadi, 2017) defines the real world as a concrete real world that is conveyed to students through mathematical applications. Starting from here it is developed the process of learning mathematics based on situations that are understood, related to students and close to the student environment.

\section{Learning Materials}

Devices used in the learning process are called learning devices. Effective learning tools can improve student activities in learning (Astawa, 2015; Marlina, 2013; Tiro, Jamal \& Mastuang, 2015). According to Simamora, Saragih and Hasratuddin (2019) that "Learning materials are materials, tools, media, instructions, and guidelines that students and teachers will use to conduct learning activities" (Nasution \& Sinaga, 2017).

To improve students' abilities in learning with a realistic mathematical education approach, the required learning tools are adapted to the realistic mathematics education approach. The learning device was developed to find devices that meet effective criteria. In this study, the learning material designed was to construct curved side spaces. Learning tools developed include: Learning Implementation Plans (RPP), Student Books (BS), Student Worksheets (LKS), Student Mathematical Spatial Ability Tests, and Student Motivation Questionnaire.

\section{RESEARCH METHOD}

This research is categorized into the type of development research. This study uses the development model Dick, Carey and Carey (2005). This study aims to find PMR-based learning devices that are effective in improving spatial abilities of mathematics and student motivation.

This research was conducted at Pulo Bandring 2 Public Middle School, one of the schools in Kisaran, Asahan district, North Sumatra, Indonesia. The subjects in this study were students of class IX SMP 2 Pulo Bandring 2018/2019 academic year. While the object in this study is a learning device that was developed based on PMR on the material to construct curved side spaces.

In this study an analysis of PMR-based learning devices developed that meets the effective criteria will be conducted. The instruments used in this study were tests and questionnaires. Tests are used to measure mathematical spatial ability and questionnaires are used to capture responses. Next, to see the effectiveness of the learning materials, which is seen from: (1) Classical learning completeness of students at least $85 \%$ of students who get a mathematical spatial ability test have obtained a minimum score of 75; (2) Achievement of learning objectives for each item in the test of mathematical spatial ability of at least 75\%; (3) At least $80 \%$ of students respond positively to the components of the learning materials developed; and (4) The learning time used does not exceed the usual learning time (Hasratuddin, 2015).

For the trial phase, a sample from class IX SMP 2 Pulo Bandring was taken. The trial class used is class IX-2 for trial I and class IX-3 for trial II. At the end of each lesson a test was conducted to measure the spatial abilities of mathematics and student motivation. In the end the trial was carried out until finally the PMRbased learning devices developed met the effective criteria.

\section{RESULT}

\section{The Description of Learning Materials Development Stage}

In this development research, learning devices based on realistic mathematical education approaches met the effective criteria in the second trial. In this study, the spatial ability of mathematics and the motivation 
of students taught with the developed learning device experienced an increase based on the acquisition of the average score of students. The results of the development learning materials using the Dick \& Carey model follow 10 steps are: (1) identify instructional goals, (2) conduct instructional analysis, (3) analyze identify entry behaviors, (4) write performance objectives, (5) develop criterion-reference tests, (6) develop instructional strategy, (7) develop and select instructional materials, (8) develop \& conduct formative evaluation, (9) revise instruction, and (10) design and conduct summative evaluation.

The result for trial I and trial II are mathematical spatial ability and motivation of the students SMP Negeri 2 Pulo Bandring was improving based on average score. The spatial ability in this study was measured based on the results of tests that were tested on students in class IX-2 (trial I) and class IX-3 (trial 2). In trial I the results of spatial ability tests were obtained with an average value of 73.84 . Whereas in trial II the results of the spatial ability test were obtained with an average value of 77.03. Based on the results of these tests, it was found 3,19 from total average from trial I to trial II and there was to improve in spatial ability of students using the realistic mathematics learning devices. The average score is shown at Table 1 below.

Table 1. The average skor in mathematical spatial ability at trial I and trial II

\begin{tabular}{cccc}
\hline Number & Trial & Number of students & Average \\
\hline 1 & Trial I & 31 & 73.84 \\
\hline 2 & Trial II & 30 & 77.03 \\
\hline \multicolumn{2}{c}{ Total average for improving ability from trial I to trial II } & 3.19 \\
\hline
\end{tabular}

Student motivation is measured based on the results of the questionnaire form tests tested to students in class IX-2 (trial I) and class IX-3 (trial 2). In class IX-2 the results of student motivation were obtained with an average score of 72.60. While in class IX-3 the results of student motivation were obtained with an average score of 78.11. Based on the results of these tests, it was found that there was an increase in student motivation by using a mathematics learning tool based on PMR. So that, improving by motivation in students has been achieved through from trial I to trial II.

Based on the results of the trial II data analysis, it was found that the learning materials developed have been effective based on indicators of the effectiveness of the learning materials that have been achieved. The results of classical completeness in mathematical spatial ability of students in the trial II, namely in the posttest was $90 \%$. This states that students have meet the value of classical completeness. Furthermore, for the criteria achieving the learning objectives in the trial II, it was achieved for each item about mathematical spatial ability. Then the average percentage of the total positive responses of students in the trial II was $94.8 \%$, and the learning time used is in accordance with the criteria for achieving learning time.

\section{DISCUSSION}

From the description above, it was found that PMR-based learning devices were effective and could improve the spatial abilities of mathematics and student motivation. Bruner (1961) gave three modes of presentation (modes of presentation), namely active, iconic, and symbolic ways. In the way of serving enaktif this is what real-world roles really need.

To answer the test of the spatial ability of mathematics carried out in accordance with the steps of the realistic mathematical education approach, namely: first understanding the contextual problem. The two try to solve the contextual problems that are given together in groups. All three compare and discuss answers with other groups. Fourth find or conclude the knowledge that has been obtained.

In learning using a realistic mathematics education approach, according to Bruner (1961), one of the most important aspects of his theory is that students construct their knowledge by linking information that enters with previously owned information. Bruner developed a cognitive learning model known as learning discovery. Bruner considers that discovery learning is in accordance with the search for knowledge actively by students, and by itself provides the best results. Trying to find solutions to problems and the knowledge that accompanies them, results in knowledge that is truly meaningful.

According to Syahputra (2013) learning with a realistic mathematic education approach can improve students' spatial ability. Noviani, Syahputra and Murad (2017) suggested that “(1) Student's spatial ability through Realistic Mathematics Education (RME) learning is better than ordinary learning, (2) Student's spatial ability before being taught with Realistic Mathematics Education (RME) is similar to students' spatial 
skills before being taught with ordinary learning; and (3) Student's spatial abilities taught by Realistic Mathematics Education (RME) improve well and also has a higher percentage of students taught by ordinary learning.

Tanjung (2017) shows that realistic mathematics education based on learning devices have met the effectiveness criteria. Significantly better in improving students' mathematical abilities. Nur and Surya (2017) related to PMR found that students respond to the teaching material that has been developed through RME is positive because more that $80 \%$ of students are intended to follow the teaching process by teaching the material that has been developed. Prastyo (2017) found that by looking at the spatial abilities of mathematics and mathematical abilities students get results that show the spatial ability of middle school students with high, medium, and low mathematical abilities.

Sabrida (2016) states that by developing effective teaching materials through PMR able to increase student learning motivation. Oktaviana (2016) argues that spatial ability plays an important role in solving students' mathematical problems. According to Wahyuni, Putri and Hartono (2015) concluded that a series of activities that have been designed through learning trajectories aim to improve students' spatial visualization abilities, involve students directly in understanding mathematical concepts, and see the development of student learning through a series of activities that students have passed. Murdani, Johar and Turmudi (2013) that learning devices developed with realistic approaches can improve their spatial abilities by studying geometric objects. In addition, the ability of the teacher to manage learning is very good and the activities of students in effective learning, as well as students' responses to positive learning, are above $80 \%$.

Suranto (2015) found that learning motivation can affect learning achievement, meaning that there is a significant influence between learning motivation and learning achievement. Next, Isdianti (2013) shows the RME has an effective on student learning motivation. Tohidi and Jabbari (2012) that "Motivation is of particular interest to educational psychologists because of the crucial role it plays in student learning". Fuadiah, Zulkardi and Hiltrimartin (2009) showed that the application of PMR was able to produce effective learning tools. Astawa (2015) concluded that with the development of learning devices carried out by following the stages of research development models Dick and Carey showed that the learning devices developed had met the effective criteria. Then Tiro, Jamal and Mastuang (2015) concluded that learning devices developed with the Dick and Carey models had met effective criteria in terms of learning outcomes tests.

\section{CONCLUSION}

Based on the discussion above, it can be concluded that learning devices based on realistic mathematic education approaches developed have met effective criteria and can improve mathematical spatial ability and students motivation. The mathematics learning devices developed can facilitate teachers and students at school.

\section{Disclosure statement}

No potential conflict of interest was reported by the authors.

\section{Notes on contributors}

Shulha Kynanda Putri - State University of Medan, Medan, Indonesia.

Hasratuddin - State University of Medan, Medan, Indonesia.

Edi Syahputra - State University of Medan, Medan, Indonesia.

\section{REFERENCES}

Alkalbani, M. S., \& Alwahaibi, S. S. (2015). Testing the Multiple Intelligences Theory in Oman. Procedia Social and Behavioral Sciences, 190, 575-581. https://doi.org/10.1016/j.sbspro.2015.10.001

Ansari, B. I. (2016). Mathematical Communication, Thinking Strategies and Learning Management. Banda Aceh: PeNA Foundation.

Astawa, I. W. Puja. (2015). Development of Analytical Geometry Learning Devices in the Field of Open Mathematics-Oriented Problems to Form Intact Professional Competencies for Prospective Mathematics Teachers. Proceedings of the 2015 National Seminar on FMIPA UNDIKSHA V. 
Azwar, \& Surya, E. (2017). Development of Learning Devices Based on Contextual Teaching and Learning Models Based on the Context of Aceh Cultural to Improve Mathematical Representation and selfefficacy of SMAN 1 Peureulak Students. Journal of Education and Practice, 8(27).

Azwar, \& Surya, E. (2017). Development of Learning Devices Based on Contextual Teaching and Learning Based on The Context of Aceh Cultural to Improve Mathematical Representation Ability. IJARIIE, 3(2), 2395-4396.

Bruner, J. S. (1961). The Act of Discovery. Harvard Educational Review, 3(1), 21-32

Colomeischi, A. A., \& Colomeischi, T. (2015). The Students' Emotional Life and Their Attitude toward Mathematics Learning. Procedia - Social and Behavioral Sciences, 174, 2818-2824. https://doi.org/10.1016/j.sbspro.2015.02.192

Dick, W., Carey, L., \& Carey, J. O. (2005). The Systematic Design Instruction. Jakarta: PT Rineka Putra.

Farida, I., Herkulana, \& Salim, I. (2015). Effect of Learning Motivation and Utilization of Learning Resources on Learning Outcomes of Students of Pontianak 11 Middle School.

Fitriani. (2014). Pengembangan Perangkat Pembelajaran Melalui Model Pembelajaran Kooperatif Tipe Jigsaw Untuk Meningkatkan Kemampuan Komunikasi Matematik Siswa di SMP Kelas VIII. Jurnal Pendidikan Matematika PARADIKMA, (Online) Vol. 7 No. 2 Agustus 2014.

Fuadiah, N. F., Zulkardi, \& Hiltrimartin, C. (2009). Development of Learning Devices in Geometry Material and Measurement with Indonesian Realistic Mathematics Education Approach at 179 Palembang Elementary School. Journal of Mathematics Education, 3(2).

Gardner, H., \& Hatch, T. (1989). Multiple Intelligence Go to School: Educational Implications of the Theory of Multiple Intelligences. American Educational Research Association, 18(8), 4-10. https://doi.org/10.2307/1176460

Hadi, S. (2017). Realistic Mathematics Education: Theory of Development and Implementation. Jakarta: PT Raja Grafindo Persada.

Hasratuddin. (2014). Mathematics Learning Now and the Future is Character Based. Didactic Mathematics Journal, 1(2).

Hasratuddin. (2015). Why Must Study Mathematics. Perdana Publishing: Medan.

Isdianti, I. (2013). The Effectiveness of the Realistic Mathematics Education Approach to the Motivation and Learning Outcomes of Angular Materials in Class III Students of Tegal State Elementary School. Unpublished thesis. Semarang: Semarang State University Education School.

Maier, P. H. (1998). Spatial geometry and spatial abilities How to make solid geometry solid? Selected Papers from the Annual Conference of Didactics of Mathematics 1996.

Marlina, M. (2013). Development of Junior High School Geometry Learning Tools with Collaborative Learning Strategies. Journal of Mathematics Education, 8(2).

Murdani, Johar, R., \& Turmudi. (2013). Development of Mathematics Learning Devices with Realistic Approaches to Increase Spatial Geometry Reasoning of Students in Arun State Middle School Lhokseumawe. Opportunity Journal, 1(2).

Nasution, T. K., \& Sinaga, B. (2017). Development of Student Worksheet Geometry Based Metacognitive Strategy Through Creative Thinking Ability. IOSR Journal of Research \& Method in Education (IOSRJRME), (4), 10-18.

Noviani, J., Syahputra, E., \& Murad, A. (2017). The Effect of Realistic Mathematic Education (RME) in Improving Primary School Students' Spatial Ability in Subtopic Two Dimension Shape. Journal of Education and Practice, 8(34).

Nur, M., \& Surya, E. (2017). The Integration of Realistic Mathematical Approach and Virtual Manipulative as an Enhancement of Students' Mathematical Representation Ability. IJARIIE, 3(2), 2395-4396.

Oktaviana, R. (2016). The Role of Students' Spatial Abilities in Resolving Mathematical Problems Related to Geometry. National Conference on Mathematics and Learning Research (KNPMP I), Proceedings Papers.

Pieronkiewicz, B. (2015). The Idea of Diagnosis and Therapy of Underachievement Syndrome in Learning Mathematics. Procedia - Social and Behavioral Sciences, 191, 2416-2421. https://doi.org/10.1016/j.sbspro.2015.04.665

Prastyo, Y. (2017). Description of Spatial Abilities of Middle School Students Viewed Based on Gender Differences and Mathematical Capabilities. Scientific Journal: SoulMat, 5(1). 
Quintero, E., Salinas, P., Mendivil, E. G., \& Ramirez, H. (2015). The Augmented Reality app for Calculus: A Proposal for the Development of Spatial Visualization. Procedia Computer Science, 75, 301-305. https://doi.org/10.1016/j.procs.2015.12.251

Sabrida, Y. (2016). Development of Culture-Based Teaching Materials with Realistic Approaches to Improve Communication Skills and Learning Motivation of Students at YMPI Tanjung Balai MTs. Unpublished thesis. Medan: UNIMED Graduate School in Medan.

Sadiq, F., \& Mutajab, N. A. (2010). Learning Mathematics with a Realistic Approach in Middle School. Yogyakarta: Center for Development and Empowerment of Educators and Mathematics Education Personnel of the National Education Department.

Safitri, A., Surya, E., Syahputra, E., \& Simbolon, M. (2017). Impact of Indonesian Realistic Mathematics Approach to Students Mathematic Disposition on Chapter Two Composition Function and Inversion Fungtion in Grade XI IA-1 Padangsidimpuan 4 High School. International Journal of Novel Research in Education and Learning, 4(2), 93-100.

Sapta, A., Hamid, A., \& Syahputra, E. (2018). Assistance of Parents in the Learning At Home. Journal of Physics: Conference series, 1114(2018), 012020. https://doi.org/10.1088/1742-6596/1114/1/012020

Sari, D. P., Syahputra, E., \& Surya, E. (2018). An Analysis of Spatial Ability and Self-efficacy of Student in Cooperative Learning by Using Jigsaw at Smas Muhammadiyah 8 Kisaran. American Journal of Education Research, 6(8), 1238-1244. https://doi.org/10.12691/education-6-8-25

Sembiring, R. K. (2010). Indonesian Realistic Mathematics Education (PMRI): Developments and Challenges. IndoMS. J.M.E, 1(1), 11-16.

Simamora, R. E., Saragih, S., \& Hasratuddin. (2019). Improving Students' Mathematical Problem Solving Learning and Learning through Guided Discovery Learning in Local Culture Context. International Electronic Journal of Mathematics Education, 8(27), 61-72

Sugiarni, R., Alghifari, E., \& Ifanda, A. R. 2018. Meningktkan Kemampuan Spasial Matematis Siswa Dengan Model Pembelajaran Problem Based Learning Berbantuan Geogebra.

Sukmadinata, N. S. (2012). Metode Penelitian Pendidikan. Bandung: PT Remaja Rosdakarya.

Suranto. (2015). The Effect of Motivation, the Atmosphere of the Environment and Learning Infrastructure on Student Learning Achievement (Case Study in Special High Schools for Women in Diponegoro Islamic High School Surakarta). Journal of Social Sciences Education, 25(2).

Syahputra, E. (2013). Increasing Spatial Ability of Students through the Application of Realistic Mathematics Learning. Yogyakarta: Cakrawala Journal. November 2013.

Tanjung, H. S. (2017). Development of Learning Devices Based on Realistic Mathematical Approaches to Improve Mathematical Communication Skills of Middle School Students. MAJU Journal, 4(1).

Tiro, C., Jamal, M. A., \& Mastuang. (2015). Development of Learning Devices Using the Guided Discovery Learning Model on the Principal Material of Light. Periodic Scientific Physical Education, 3(2).

Tohidi, H., \& Jabbari, M. M. (2012). The Effect of Motivation in Education. Procedia - Social and Behavioral Sciences, 31(2012), 820-824. https://doi.org/10.1016/j.sbspro.2011.12.148

Trianto. (2011). Designing Innovative-Progressive Learning Models. Concept of Platform, and its Implementation in Education Unit Level Curriculum (KTSP). Jakarta: Kencana Prenada Media Group.

Veloo, A., \& Zubainur, C. M. (2014). How A Realistic Mathematics Educational Approach Affect Students 'Activities In Primary Schools? Procedia - Social and Behavioral Sciences, 159(2014), 309-313. https://doi.org/10.1016/j.sbspro.2014.12.378

Vygotsky, L. S. (1978). Mind in Society: The Development of the Higher Psychological Processes. Cambridge, MA: The Harvard University Press.

Wahyuni, R., Putri, R. I. I., \& Hartono, Y. (2015). Cubes and Beams Volume Involves Spatial Visualization Ability in Class VIII, 1(2), 41-51.

Zulfahmi., Syahputra, E., \& Fauzi, K. M. A. (2017). Development of Mathematics Learning Tools Based Van Hiele Model to Improving Spatial Ability and Self-Concept Student's of MTs.S Ulumuddin. American Journal of Education Research, 5(10), 1080-1086. https://doi.org/10.12691/education-5-10-9 